\title{
$S$-genotyping Supports the Genetic Relationships between Turkish and Hungarian Apricot Germplasm
}

\author{
Júlia Halász ${ }^{1}$ and Andrzej Pedryc \\ Corvinus University of Budapest, Department of Genetics and Plant Breeding, P.O. Box 53, Budapest, \\ H-1518, Hungary \\ Sezai Ercisli \\ Department of Horticulture, Ataturk University, 25240, Erzurum, Turkey
}

Kadir Ugurtan Yilmaz

Malatya Fruit Research Institute, 44200, Malatya, Turkey

\begin{abstract}
Attila Hegedús
Corvinus University of Budapest, Department of Genetics and Plant Breeding, P.O. Box 53, Budapest, H-1518, Hungary
\end{abstract}

\begin{abstract}
AdDitional INDex words. crop evolution, PCR analysis, Prunus armeniaca, self-incompatibility, $S$-haplotype-specific F-box, $S$-ribonuclease

Abstract. The $S$-genotypes of a set of Turkish and Hungarian apricot (Prunus armeniaca L.) cultivars were determined by polymerase chain reaction (PCR) amplification of their $S$-RNase intron regions. In addition, the $S$-genotyping method was extended to the $S F B$ gene to detect the non-functional $S_{\mathrm{C}}$-haplotype and hence reliably identify self-compatible apricot cultivars. We determined the complete $S$-genotype of 51 cultivars and the partial $S$-genotype of four cultivars. A total of 32 different $S$-genotypes were assigned to the 51 cultivars, and many of them (28) were classified into newly established cross-incompatibility groups III through XIV. Another 12 cultivars demonstrated unique incompatible genotypes and seven self-compatible cultivars were identified in the examined accessions. The fact that Turkish and Hungarian apricot cultivars carry 12 and five $S$-alleles, respectively, and all five alleles detected in Hungarian cultivars were also present in Turkish apricots furnished molecular evidence supporting the long-suspected historical connection between Hungarian and Turkish apricots. The connection between these two gene pools appeared to be relatively recent and associated with historical events dating back 300 years. Our results confirm that Turkish germplasm contributed considerably to the development of several desirable Hungarian apricot cultivars. Results suggest that the mutation rendering the $S_{\mathrm{C}}$-haplotype non-functional might have occurred somewhere east of central Turkey.
\end{abstract}

Apricot is thought to have originated in China, from where it was disseminated to Europe through central Asia and Asia Minor (Faust et al., 1998). According to Kostina (1969), apricot cultivars are classified into four major eco-geographical groups: central Asian, Irano-Caucasian, European, and Dzhungar-Zailing (Tien-shan area). The central Asian and Irano-Caucasian (encompassing Turkish cultivars) groups show the richest phenotypic variability, while the European group (including cultivars grown in North America, Australia, and South Africa) is said to have the least diversity (Mehlenbacher et al., 1991). Apricot cultivars originating in the eastern Europe cultivar group can be clearly distinguished in their pomological characteristics from other cultivars within the European origin (Faust et al., 1998; Kostina, 1970).

The Irano-Caucasian apricots were described as predominantly self-incompatible (SI), while most European apricots are self-compatible (SC) (Halász et al., 2005; Kostina, 1970).

Received for publication 3 May 2010. Accepted for publication 24 June 2010. This work was funded by the OTKA PD78124 project and was also supported by the János Bolyai Research Scholarship of the Hungarian Academy of Sciences. Júlia Halász acknowledges a Junior Prima Prize in science (2008).

We thank Craig A. Ledbetter for critically revising the English of the manuscript. ${ }^{1}$ Corresponding author. E-mail: julia.halasz@uni-corvinus.hu.
Cross-incompatibility, resulting in the mutual failure of fruit set between a pair of cultivars, occurs frequently in predominantly SI species. In apricot, the first cross-incompatibility group was described among the North American cultivars, Goldrich, Hargrand, and Lambertin-1 (Egea and Burgos, 1996), while the second group encompassed giant-fruited Hungarian apricots (Szabó and Nyéki, 1991).

Similar to other Prunus L. species, apricots reportedly demonstrate gametophytic self-incompatibility controlled by a single locus with multiple variants, termed $S$-haplotypes (de Nettancourt, 2001). The $S$-haplotype contains a gene ( $S$-RNase) encoding for a ribonuclease enzyme (McClure et al., 1989), and the recently identified $S$-haplotype-specific F-box gene (Entani et al., 2003; Romero et al., 2004) responsible for pistil and pollen functions, respectively (Fig. 1).

To date, $21 S$-RNase alleles have been described in European apricots, 20 of which $\left(S_{1}-S_{20}\right)$ code for self-incompatibility and one $\left(S_{\mathrm{C}}\right)$ allowing self-compatibility (Burgos et al., 1998; Halász, 2007; Halász et al., 2005, 2007a). The $S_{\mathrm{C}}$-haplotype was long suspected and recently confirmed to be a pollen-part mutant of the $S_{8}$-haplotype (Halász et al., 2007a) with a 358-bp insertion in the $S F B_{\mathrm{C}}$ gene (Vilanova et al., 2006). Additional $S$-alleles have been identified in Chinese cultivars (Wu et al., 2009). 


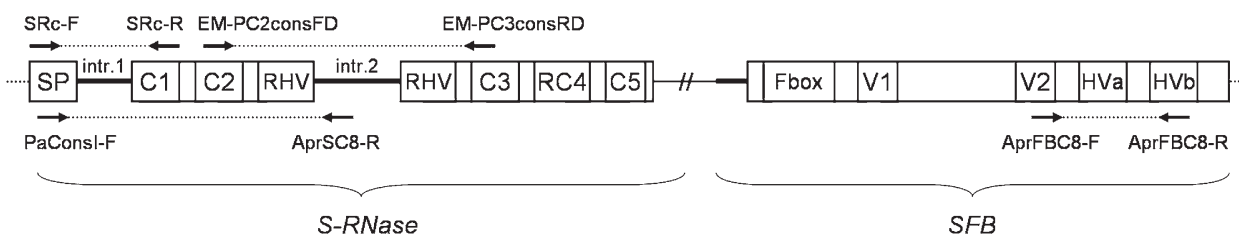

Fig. 1. Schematic structure of the $S$-locus in apricot and annealing sites of the consensus (above) and allele-specific (below) primers used for the PCR analysis. Boxes and lines are exons and introns, respectively (not to scale).

analyzed by spectrophotometer (NanoDrop $^{\text {TM }}$ ND-1000; Bio-Science, Budapest, Hungary).

GENOMIC PCR With S-RNase AND $S F B$-SPECIFIC PRIMERS. PCR was conducted according to Sutherland et al. (2004) using the degenerate primers EM-PC2consFD and EM-PC3consRD for the amplification of the second intron region of

Microsatellite analyses suggested that Hungarian and European cultivars might have originated through hybridization among Irano-Caucasian genotypes (Maghuly et al., 2005). This assumption seems to be confirmed by historical and linguistic evidence, as well. During the one and a half centuries of Ottoman occupation in Hungary, abundant records exist to document the admission of Turkish graft-wood and other propagation materials to Hungary (Faust et al., 1998). Even the Hungarian word used for this fruit crop, "kajszi," has a Turkish origin as "kaysi," meaning superior, sweet-seeded, and grafted apricots in contrast with the world "zerdali," used for old, local seedlings with smaller fruit and bitter seed (Ercisli, 2004).

Turkey dominates world apricot production with more than 700,000 Mt produced in 2008 (Food and Agriculture Organization of the United Nations, 2008). As considerable genetic variability exists in Turkish apricot germplasm, and this crop is of great economical significance, many detailed analyses have been performed in recent years on morphological and pomological characterization, as well as on fruit quality, yield, and fertilization characteristics of Turkish apricots (Akin et al., 2008; Asma and Ozturk, 2005; Gülcan et al., 2006). However, discrepancies between study years for orchard bagging studies and pollen tube growth analyses have led to uncertainty of the self-incompatibility genotypes for many Turkish cultivars (Misirli et al., 2006).

In this study, we used polymerase chain reaction (PCR) amplification of the $S$-RNase intron regions to determine their lengths and the $S$-genotypes of a set of Turkish apricot cultivars. In addition, the $S$-genotyping method was extended to the $S F B$ gene to detect the non-functional $S_{\mathrm{C}}$-haplotype and hence reliably identify SC apricot cultivars. The information was then compared with $S$-genotypes of Hungarian apricots to establish a possible relationship between Turkish and Hungarian apricot germplasm.

\section{Materials and Methods}

Plant material. The 55 Turkish apricot cultivars used in the experiments were obtained as chance seedlings and were characterized by phenotypic diversity and geographic origin (Table 1). All cultivars were grown at Malatya Fruit Research Institute, Malatya, Turkey. Six cultivars with known $S$-genotypes [Bergeron $\left(S_{2} S_{\mathrm{C}}\right)$, Ceglédi óriás $\left(S_{8} S_{9}\right)$, Goldrich $\left(S_{1} S_{2}\right)$, Mari de Cenad $\left(S_{\mathrm{C}} S_{19}\right)$, Moniquí $\left(S_{2} S_{6}\right)$, and Sunglo $\left(S_{2} S_{3}\right)$ (Burgos et al., 1998; Halász, 2007; Halász et al., $2005,2007 \mathrm{a})$ ] were used as controls and were obtained from the orchard of the Corvinus University of Budapest, Department of Genetics and Plant Breeding, Szigetcsép, Hungary.

DNA Extraction. Genomic DNA was extracted from fully expanded young leaves using a DNeasy Plant Mini Kit (Qiagen, Hilden, Germany). The quantity and quality of DNA were the S-RNase gene (Fig. 1). To amplify the first intron, the fluorescently labeled (JOE) forward primer SRc-F (Romero et al., 2004) was used in combination with the reverse primer SRc-R (Vilanova et al., 2005).

For the identification of the $S_{\mathrm{C}}$-haplotype, a two-step approach was used. An allele-specific reverse primer, AprSC8R (CTAATAACTAAATGCTAAAGAGCA) was designed to selectively amplify the $S_{\mathrm{C}} / S_{8}$-RNase allele (Fig. 1) and was used in combination with PaConsI F (Sonneveld et al., 2003). The amplification was carried out using a temperature profile with an initial denaturing of $94{ }^{\circ} \mathrm{C}$ for $2 \mathrm{~min}, 35$ cycles of $94{ }^{\circ} \mathrm{C}$ for $30 \mathrm{~s}, 55^{\circ} \mathrm{C}$ for $1.5 \mathrm{~min}$ and $72{ }^{\circ} \mathrm{C}$ for $2 \mathrm{~min}$, and a final extension of $72{ }^{\circ} \mathrm{C}$ for $5 \mathrm{~min}$. $S F B_{\mathrm{C}} / S F B_{8}$-specific primers, AprFBC8-F (5' -CATGGAAAAAGCTGACTTATGG-3') and AprFBC8-R (5'-GCCTCTAATGTCATCTACTCTTAG-3') were designed based on the $\mathrm{V} 2$ and $\mathrm{HVb}$ variable region of the $S F B_{\mathrm{C} / 8}$ allele (Halász et al., 2007a) (Fig. 1). The amplification was carried out as described for the $S_{\mathrm{C}} / S_{8}$-RNase-specific primers.

PCR was carried out in a thermocycler (PTC 200; MJ Research, Budapest, Hungary). For amplification of the $S$-RNase first and second introns, we used the programs originally described for the primers (Sutherland et al., 2004; Vilanova et al., 2005). About 20 to $80 \mathrm{ng}$ of genomic DNA was used for PCR amplification in a $25-\mu \mathrm{L}$ reaction volume, containing $1 \times$ PCR buffer (Sigma, Budapest, Hungary) with final concentrations of $10 \mathrm{~mm}$ Tris- $\mathrm{HCl}$ (pH 8.3), $50 \mathrm{~mm} \mathrm{KCl}, 1.5 \mathrm{mM} \mathrm{MgCl}_{2}$, $0.2 \mathrm{~mm}$ of dNTPs, $0.4 \mu \mathrm{M}$ of each primer, and $0.625 \mathrm{U}$ of Taq DNA polymerase (Sigma).

The PCR products were separated on $2 \%$ TAE agarose gels at $100 \mathrm{~V}$ for $2 \mathrm{~h}$ and DNA bands were stained with ethidium bromide. Fragment sizes were estimated by comparison with the $1 \mathrm{~kb}+$ DNA ladder (Promega, Madison, WI). For exact size determination of $S$-RNase first intron region fragments smaller than $500 \mathrm{bp}$, the fluorescently labeled products were run in an automated sequencer ABI PRISM 3100 Genetic Analyzer (Applied Biosystems, Budapest, Hungary) using the GENOTYPER 3.7 software and GS500 LIZ size standard (Applied Biosystems).

\section{Results}

Determination of the $S$-genotypes of 55 Turkish apricot cultivars was carried out using the SRc-F and SRc-R consensus primers (Vilanova et al., 2005) for the first intron and the EMPC2consFD and EM-PC3consRD primers (Sutherland et al., 2004) for the second intron analysis. The sizes of the PCR products obtained were compared with those previously published by Vilanova et al. (2005) and Halász (2007). Primers designed from conserved coding regions flanking the second intron yielded two fragments ranging from 310 to $1980 \mathrm{bp}$, except in the cases of 17 cultivars where only one fragment was amplified (Fig. 2). Four cultivars did not show PCR products at all. 
Table 1. Name of apricot cultivars collected from different Turkish regions, as well as their ripening time, skin color, fruit firmness, size, use, selfincompatibility status, and $S$-genotype.



${ }^{\mathrm{z}} \mathrm{SI}=$ self-incompatible, $\mathrm{SC}$ = self-compatible; self-(in)compatibility phenotypes supported by fruit set ratios after self-pollination (Gülcan et al., 2006) are underlined.

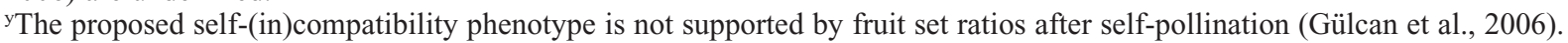

${ }^{x}$ Unknown alleles were labeled as $S_{\text {? }}$.

w'Kayisi Erigi' is a natural hybrid of Prunus armeniaca and Prunus salicina; hence, its unidentified $S$-allele was transmitted from the plum parent. 

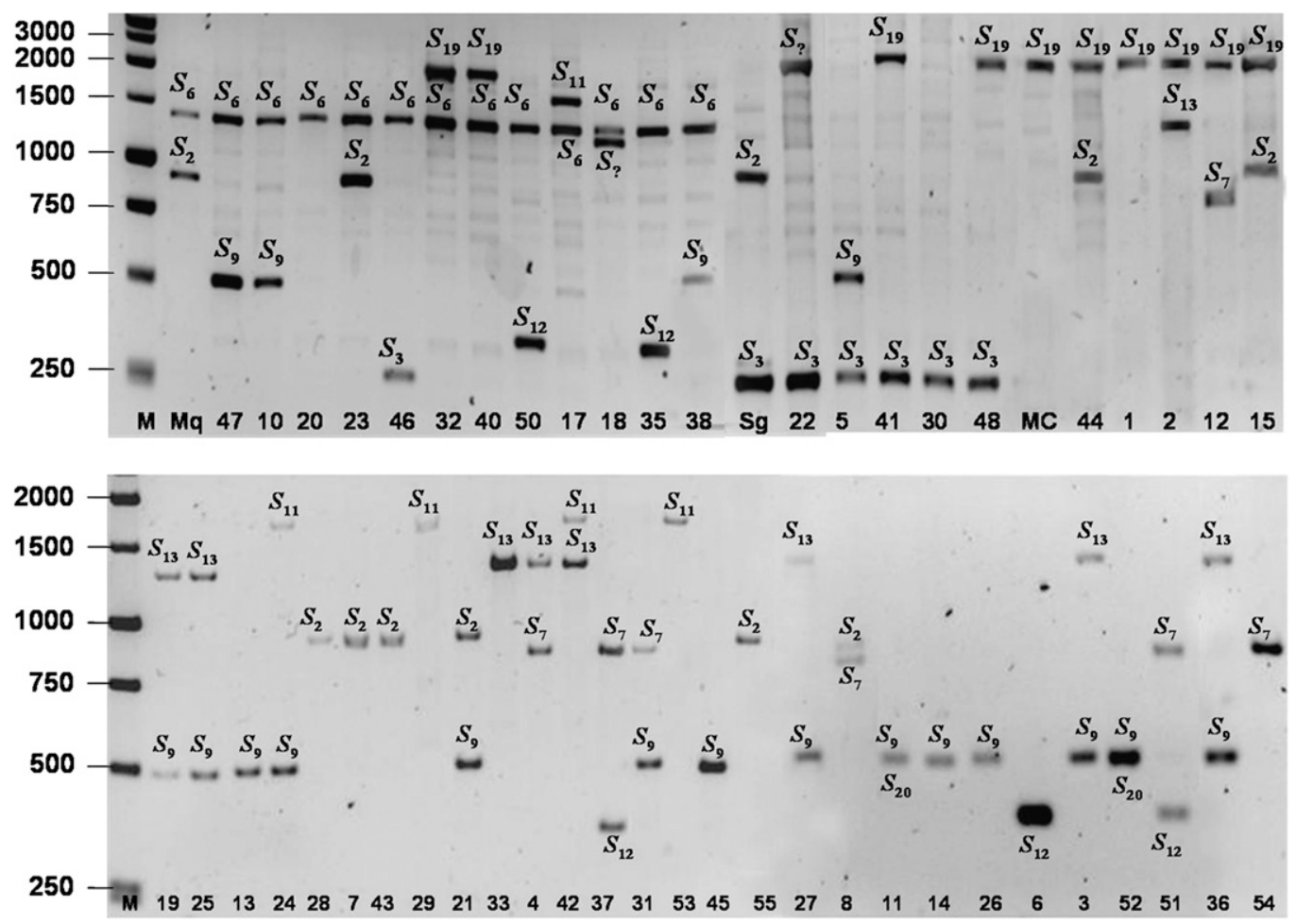

Fig. 2. PCR products (in negative) in 50 Turkish and three control apricot cultivars using the second intron consensus primers of Prunus $S$-RNase gene $[\mathrm{M}=1 \mathrm{~kb}+$ DNA ladder, $\mathrm{Mq}=$ 'Moniquí' $\left(S_{2} S_{6}\right), \mathrm{Sg}=$ 'Sunglo' $\left(S_{2} S_{3}\right), \mathrm{MC}=$ 'Mari de Cenad' $\left.\left(S_{\mathrm{C}} S_{19}\right)\right]$. Numbers refer to cultivars shown in Table 1 .

For nine Turkish cultivars (Alyanak, Artvin P.A., Dörtyol 4, Hasanbey, Iri Bitirgen, Karacabey, Sam, Sebbiyiki, and Ziraat Okulu) and two control cultivars (Moniquí and Sunglo) a fragment of $\approx 900 \mathrm{bp}$ was detected that indicated the presence of allele $S_{2}$. A fragment of $\approx 310 \mathrm{bp}$ occurred in six Turkish cultivars (Akcadag Günay, Imrahor, Kayseri P.A., Sakit 3, Sekerpare, and Tokaloglu Izmir) and Sunglo, confirming this allele as $S_{3}$. Twelve cultivars (Cataloglu, Hacikiz, Gec Aprikoz, Güz Aprikozu, Iri Bitirgen, Levent, Ozal, No 1 Zerdali, Sakit 1, Sekerpare, Soganci, and X1 Zerdali) yielded a fragment of $\approx 1300 \mathrm{bp}$, similar to 'Moniquí' $\left(S_{2} S_{6}\right)$ and hence this allele was labeled $S_{6}$. The allele $S_{7}$ occurred in eight cultivars (Agerik, Artvin P.A., Cigli, Kurukabuk, Ordubat, Turfanda Izmir, X2 Zerdali, and Yerli Izmir) as a fragment of $\approx 820 \mathrm{bp}$.

$\mathrm{An} \approx 500$-bp fragment was detected in 18 cultivars (Adilcevaz 5, Akcadag Günay, Cataloglu, Cekirge 52, Cologlu, Dörtyol 2, Haci Haliloglu, Hasanbey, Ismailaga, Kabaasi, Kadioglu, Kamelya, Kurukabuk, No 2 Zerdali, Ozal, Seftalioglu, Soganci, and X3 Zerdali), which could be attributed to allele $S_{9}$ or $S_{20}$. Determination of the sizes of the first intron region would be required to distinguish between these alleles. An $\approx 1700$-bp fragment appeared in five cultivars (Gec Aprikoz, Ismailaga, Kayisi Erigi, Shalakh, and Yegen), indicating the presence of $S_{11}$-allele. A fragment size characteristic for allele $S_{12}$ was observed in five cultivars (Alioglu 49, No 1 Zerdali, Ordubat, $\mathrm{X} 1$ Zerdali, and $\mathrm{X} 2$ Zerdali). A band of $\approx 1250 \mathrm{bp}$ appeared in nine cultivars (Adilcevaz 3, Adilcevaz 5, Agerik, Haci Haliloglu, Kabaasi, Kamelya, Mahmudun Erigi, No 2 Zerdali, and Shalakh), suggesting that the $S_{13}$-allele is common to all. The allele $S_{19}$ has a second intron region $(\approx 1980 \mathrm{bp})$, which was found in nine cultivars (Adilcevaz 1, Adilcevaz 3, Cigli, Dörtyol 4, Levent, Sakit 1, Sakit 3, Sebbiyiki, and Tokaloglu Izmir).
The identity of this allele was further supported by using a control cultivar, Mari de Cenad $\left(S_{\mathrm{C}} S_{19}\right)$.

'Kayisi Erigi' is a hybrid of $P$. armeniaca and Prunus salicina Lindl. Its $S_{11}$-allele is derived from the apricot parent, but the other allele differs from all apricot alleles and must have originated from the plum ( $P$. salicina) parent. The 1270- and 1950-bp sizes of the second intron region in 'Güz Aprikozu' and 'Imrahor', respectively, do not match the sizes of any known alleles. The novelty of these alleles must be verified by DNA sequencing.

To support the $S$-genotype determinations, precise first intron lengths were also determined for all cultivars using fluorescently labeled primers and automated sizing of the first intron regions. Based on the second intron region analysis, 18 cultivars remained undistinguished with regard to their $S_{9^{-}}$or $S_{20}$-alleles. However, the first intron sizes of these two alleles differ from each other: $S_{9}$ is characterized by a fragment of 203 bp, while the size of $S_{20}$ is $222 \mathrm{bp}$. Determination of the precise fragment sizes revealed that all 18 cultivars carried the $S_{9^{-}}$ allele, and two of them (Cekirge 52 and X3 Zerdali) also harbored the $S_{20}$-allele.

In the study of Vilanova et al. (2005), the accurate size of fragments amplified by the SRc-F primer pair from $S_{3^{-}}$and $S_{6}$ alleles was not determined. Using 'Sunglo' $\left(S_{2} S_{3}\right)$ and 'Moniquí' $\left(S_{2} S_{6}\right)$ as control cultivars, the sizes of the first intron region of the $S_{3}$ - and $S_{6}$-alleles were determined in the present study as 269 and $423 \mathrm{bp}$, respectively.

Two peaks were observed for 51 accessions, while four cultivars (Canakkale, Ethembey, Mektep, and Pasa Mismisi) had only one fragment of $355 \mathrm{bp}$. These four cultivars were also similar in that they did not give amplification in the second intron region. The 355-bp fragment was also present in 14 other cultivars. This fragment size was previously attributed to the 
$S_{\mathrm{C}^{-}}$and $S_{8}$-RNase alleles (Halász et al., 2007a). To confirm that no other unidentified alleles could give rise to a fragment with a first intron region size identical to $S_{\mathrm{C}}$ and $S_{8}$, a specific primer (AprSC8) was designed to anneal exclusively within the second intron region of the $S_{\mathrm{C}^{-}}$and $S_{8}-R N a s e$ alleles. This primer pair selectively amplified a fragment of $547 \mathrm{bp}$ only in the case of $S_{8} / S_{\mathrm{C}}$-alleles, as demonstrated by using control cultivars Ceglédi óriás $\left(S_{8} S_{9}\right)$ and Bergeron $\left(S_{\mathrm{C}} S_{2}\right)$. In contrast, there was no amplification in 'Goldrich' $\left(S_{1} S_{2}\right)$ when used as a negative control (Fig. 3A). The presence of $S_{8} / S_{\mathrm{C}}$-alleles was indeed confirmed among the tested 18 Turkish cultivars.

Because coding regions of the $S_{8^{-}}$and $S_{\mathrm{C}}$-RNase alleles are identical, discrimination of SI from SC cultivars could not be achieved in this analysis. The $S_{8^{-}}$and $S_{\mathrm{C}}$-haplotypes differ only in the $S F B$ gene in that an insertion of $358 \mathrm{bp}$ can be found in the $S F B_{\mathrm{C}}$, resulting in a truncated protein and the consequent breakdown of self-incompatibility. Using a new primer pair (AprFBC8), we could distinguish between the SI and SC cultivars because genotypes carrying the $S F B_{\mathrm{C}}$-allele showed an amplification product of $\approx 500 \mathrm{bp}$, while genotypes carrying the $S F B_{8}-$ allele showed a fragment of $\approx 150 \mathrm{bp}$ (Fig. 3B). Additionally, the primer worked as a codominant marker because homo- and heterozygotes could be unequivocally differentiated. Altogether, seven cultivars (Canakkale, Ethembey, Kayisi Erigi, Mektep, Pasa Mismisi, Sam, and Yerli Izmir) proved to be self-compatible, six were heterozygotes, and only one homozygote, 'Canakkale' $\left(S_{\mathrm{C}} S_{\mathrm{C}}\right)$, was identified. Three cultivars shared the $S_{\mathrm{C}} S_{8}$-genotype (Ethembey, Mektep, and Pasa Mismisi) as demonstrated by two fragments of appropriate sizes in the agarose gel (Fig. 3B).

Finally, we determined complete $S$-genotypes of 51 cultivars and partial $S$-genotypes of four cultivars by combining the results obtained in two rounds of PCR (Table 1). Twelve previously described $S$-alleles were identified among the Turkish cultivars. $S_{9}$ was the most frequent $S$-allele in the tested Turkish germplasm (occurring in 18 cultivars), followed by $S_{8}(14), S_{6}(12), S_{2}, S_{13}$ and $S_{19}(9), S_{7}(8), S_{\mathrm{C}}(7), S_{3}(6), S_{11}$, and $S_{12}(5)$, while $S_{20}$-allele was only found in two cultivars.

\section{Discussion}

$S$-GENOTYPES OF TURKISH CULTIVARS. While the $S$-genotypes of many North American and European apricot cultivars are

\section{A}

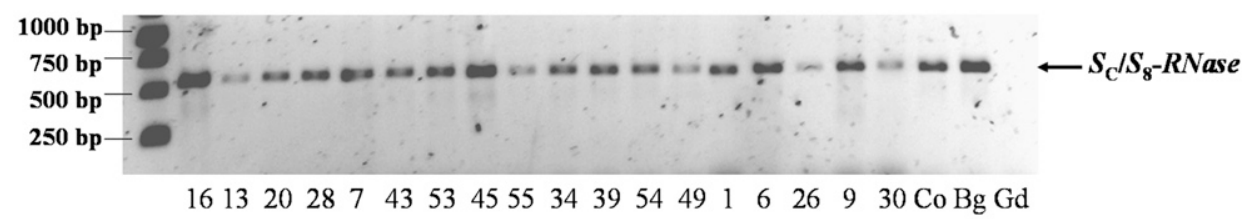

B

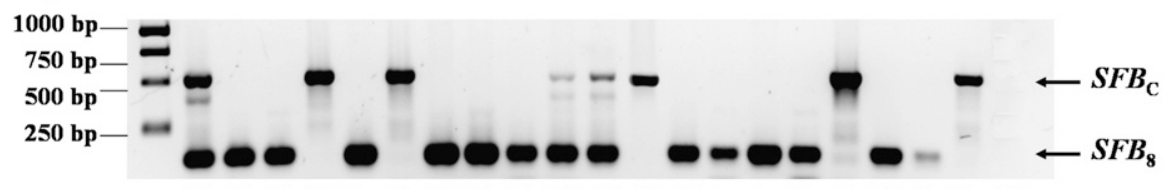

$1613202874353455534395449 \quad 1 \quad 6 \quad 26 \quad 9 \quad 30 \quad \mathrm{Co} \mathrm{Bg} \mathrm{Gd}$

Fig. 3. PCR detection and reliable differentiation of $S_{\mathrm{C}^{-}}$and $S_{8}$-haplotypes in Turkish apricots. Allele-specific PCR reaction (A) was used to control the presence of the $S_{8 / \mathrm{C}}-R N a s e$ alleles and a selective amplification of the $S F B$ gene $(\mathbf{B})$ was used to differentiate between $S F B_{\mathrm{C}}$ and $S F B_{8}$ alleles $[\mathrm{M}=1 \mathrm{~kb}+\mathrm{DNA}$ ladder, $\mathrm{Co}=$ 'Ceglédi óriás' $\left(S_{8} S_{9}\right), \mathrm{Bg}=$ 'Bergeron' $\left(S_{2} S_{\mathrm{C}}\right), \mathrm{Gd}=$ 'Goldrich' $\left.\left(S_{1} S_{2}\right)\right]$. Numbers 1 through 50 refer to cultivars shown in Table 1. known, this is the first study to examine $S$-genotype diversity of apricots native to Turkey, the leading apricot producer in the world. As such, this information can be used directly by producers in making correct selections of pollination partners in new orchard plantings, as well as by researchers interested in clarification of the evolutionary history of this crop.

Complete $S$-genotypes were given for 51 apricot cultivars. For four others, only partial $S$-genotypes could be determined. A total of 32 different $S$-genotypes were assigned to the 51 cultivars with complete $S$-genotypes. Many of them (28) were proposed to form new cross-incompatibility groups, III-XIV. Previously, two groups were described, group I for North American cultivars (Egea and Burgos, 1996) and group II for Hungarian giantfruited cultivars (Szabó and Nyéki, 1991). The limited number of groups identified in former studies might be associated with the fact that most of the tested European cultivars were SC alasz et al., 2007a; Vilanova et al., 2005). In other SI Prunus 19 groups are known for almond [Prunus dulcis (Mill.) D.A. Webb], sweet cherry (Prunus avium L.), and japanese plum P. salicina), respectively (Guerra et al., 2009; Halász et al., 007b, 2010; Ortega et al., 2006; Schuster et al., 2007; Tobutt cultivars was previously confirmed by fruit set analysis in Turkey (Gülcan et al., 2006; Misirli et al., 2006).

Another 12 cultivars demonstrated unique incompatible genotypes, which can be used as universal pollen donors because they are mutually compatible with all 14 crossincompatibility groups. Among the 55 cultivars, only seven selfcompatible genotypes were determined. Six of these cultivars re also checked and confirmed for self-fruitful phenotype in fruit set analyses (Gülcan et al., 2006). The $S_{\mathrm{C}} S_{\mathrm{C}}$ homozygote 'Canakkale' showed outstanding levels (over 30\%) of fruit set after self-pollination over 2 years.

Based on fruit set analysis after self-pollination, Gülcan et al. (2006) determined fruit set ratios exceeded 5\% for another seven cultivars of those tested here and proposed to be SI in this study. Considering that fruit set ratios were only slightly higher than $5 \%$ for four cultivars and data were somewhat inconsistent ween years, our study confirmed that results from open-field fruit set analyses can only be regarded as reliable if consistent results are available from several years. The remaining three cultivars (Cekirge-52, Imrahor, and Sakit-1) were reported to produce fruit set ranging from $14 \%$ to $34 \%$ (Gülcan et al., 2006). However, these cultivars do not carry the $S_{\mathrm{C}}$-haplotype. If the self-fruitful phenotype of these cultivars and the identity of plant materials can be confirmed, mutation would be a possibility that renders the $S$-locus nonfunctional in these genotypes.

Crop eVolutionary perspecTIVES. A gradually decreasing allele number was detected in apricot landraces from China to western Europe, with some allelic exclusivity occurring in certain geographic areas (Halász, 2007). For example, alleles $S_{10}-S_{14}$ were only detected in apricots of Armenian origin (Halász 
et al., 2005), while alleles $S_{8}, S_{9}, S_{19}$, and $S_{20}$ were only found in Hungarian apricots (Halász, 2007; Halász et al., 2007a). In the present study, $S_{11}-S_{13}$ alleles were also detected in Turkish apricots, most frequently in those originating from the eastern part of the country, near the Turkish-Armenian border.

In addition, each allele that was previously detected only in Hungarian cultivars was relatively frequent in Turkish apricots. Even cross-incompatibility group II, encompassing the giant fruited Hungarian cultivars, expanded with the addition of the Turkish apricots (Table 2). The fact that Turkish and Hungarian apricot cultivars carry 12 and five $S$-alleles, respectively, and all five alleles detected in Hungarian cultivars were also present in Turkish apricots furnished molecular evidence to support historical records that apricots were intensively transferred to Hungary from Turkey during the 15 th and 16th centuries (Faust et al., 1998). After the Ottoman retreat, apricot orchards were abandoned and sometimes devastated. However, apricot trees could survive these intervals from seeds or as escaped individuals. It has been shown that selection may lead to significant genetic gain in apricot (Ledbetter, 2008). The imported Turkish material was likely subjected to natural and human selection pressures that resulted in some landrace cultivars being well adapted to Hungarian ecological conditions and having valuable pomological characteristics. It also explains why present-day Hungarian and Turkish apricot cultivars differ from each other in many respects.

Most of the present Hungarian cultivars were selected four or five decades ago in regions overlapping with the former Turkish estates and orchards (Faust et al., 1998). For example, a Hungarian cultivar Korai piros carries the rare $S_{20}$-allele that was also identified in two Turkish landrace cultivars. 'Korai piros' was found in the area formerly occupied and controlled by the Turks for more than 100 years (Harsányi, 1981). Genetic relatedness between Hungarian and Irano-Caucasian apricots was also demonstrated by simple sequence repeat (SSR) analysis (Maghuly et al., 2005). However, the connection between these germplasm sources seems to be relatively recent and associated with historical events only 300 years ago rather than primary dissemination routes of apricot from central Asia to Europe dating back 2000 years, as previously believed (Faust et al., 1998; Maghuly et al., 2005).

We must highlight that the same $S_{\mathrm{C}}$-haplotype associated with the SC phenotype of all European cultivars has been detected in Turkish apricots as well. It is interesting to realize that most of the SC cultivars originated at the western or central part of the country, while no SC cultivars could have been found among the cultivars from eastern Turkey (Fig. 4). However, the non-mutated, wild-type of the $S_{\mathrm{C}}$-haplotype $\left(S_{8}\right)$ was quite frequent in that region. It may indicate that the mutation rendering the $S_{\mathrm{C}}$-haplotype non-functional could have occurred somewhere close to the region east from central Turkey. However, this hypothesis requires further support.

If the $S_{\mathrm{C}}$-haplotype had been brought to Hungary, it would have allowed self-fertilization and reliable fruit set. The Hungarian Magyarkajszi cultivars are well known in central Europe, and all share the $S_{\mathrm{C}} S_{8}$ genotype. Among the Turkish cultivars, three have the same $S_{\mathrm{C}} S_{8}$ genotype (Ethembey, Mektep, and Pasa Mismisi). These cultivars are characterized by medium or large fruit size, and two of them are used for fresh consumption (Table 1) similar to the Hungarian Magyarkajszi cultivars. It would be interesting to know whether these cultivars or their ancestors contributed to the formation of the present Hungarian Magyarkajszi cultivars. Additional molecular analyses (SSR or SNP) might be used to control this possibility.

\section{Conclusions}

Our results show that most Turkish apricots are SI, hence, $S$-genotyping may help to achieve reliable fruit set in commercial

Table 2. Cross-incompatibility groups of apricot. Cultivars with previously determined $S$-genotypes (Egea and Burgos, 1996; Halász et al., 2005) are set in italics.

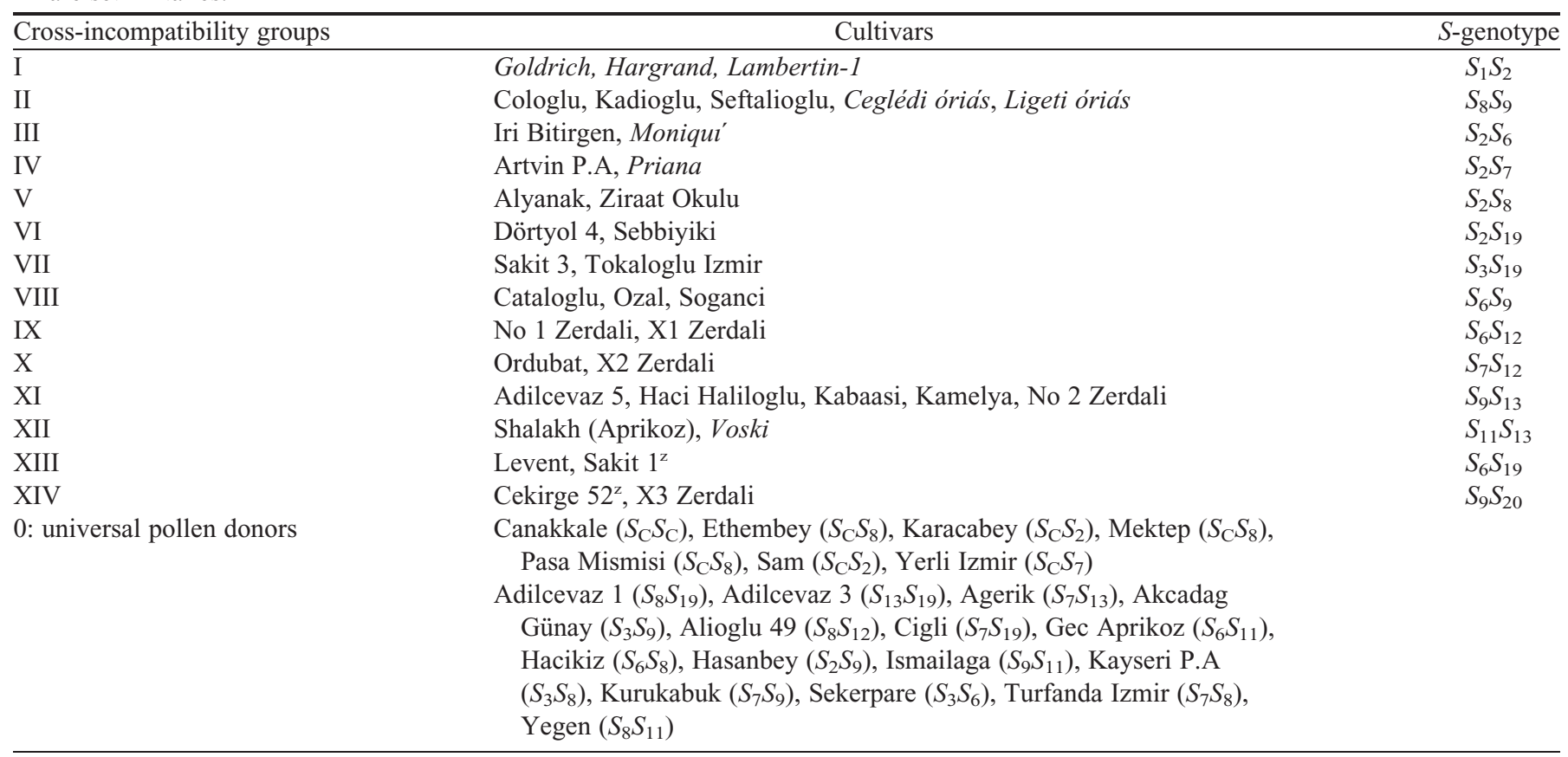

${ }^{\mathrm{z}}$ Further analyses are required to confirm self-incompatibility phenotype. 


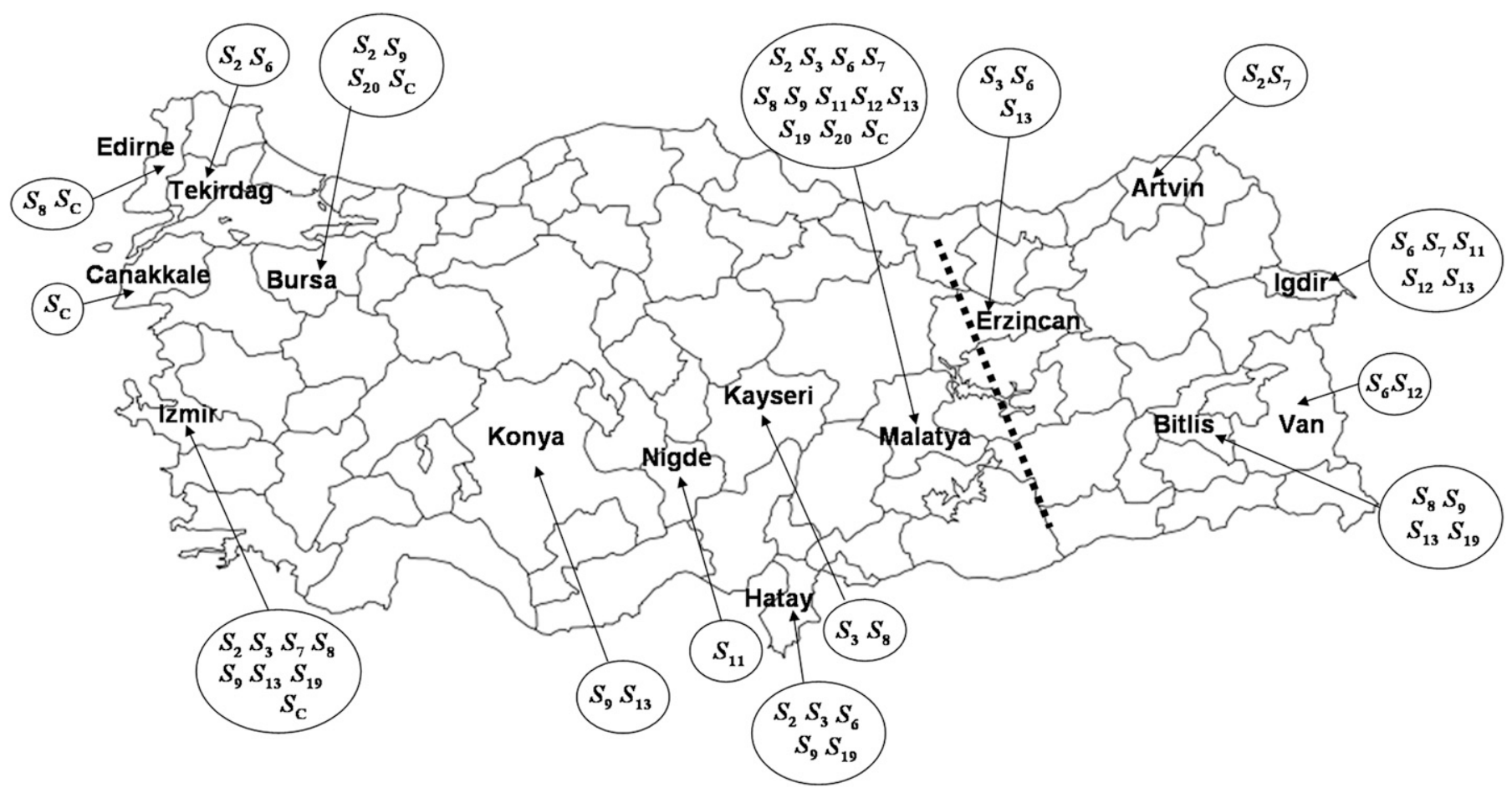

Fig. 4. Distribution of $S$-alleles detected in apricot cultivars from different growing areas in Turkey. West of the broken line, self-compatible cultivars were detected, while east of the line, self-compatible cultivars did not occur.

orchards of the world's largest apricot-producing country. It is also highlighted by the fact that 12 new cross-incompatibility groups have been proposed among Turkish apricots in contrast with only two cross-incompatibility groups previously described among European and North American cultivars. Our results support the hypothesis that Turkish germplasm contributed considerably to the formation of precious Hungarian apricot cultivars. The realization of the shared $S$-allele pools of the Irano-Caucasian and European apricots confirms previous crop evolutionary hypotheses and phylogenetic data, and also holds possibilities for breeding in Turkey and other European countries.

\section{Literature Cited}

Akin, E.B., I. Karabulut, and A. Topcu. 2008. Some compositional properties of main Malatya apricot (Prunus armeniaca L.) varieties. Food Chem. 107:939-948.

Asma, B.M. and K. Ozturk. 2005. Analysis of morphological, pomological and yield characteristics of some apricot germplasm in Turkey. Genet. Resources Crop Evol. 52:305-313.

Burgos, L., O. Pérez-Tornero, J. Ballester, and E. Olmos. 1998. Detection and inheritance of stylar ribonucleases associated with incompatibility alleles in apricot. Sex. Plant Reprod. 11:153-158.

de Nettancourt, D. 2001. Incompatibility and incongruity in wild and cultivated plants. 2nd ed. Springer-Verlag, New York.

Egea, J. and L. Burgos. 1996. Detecting cross-incompatibility of three North American apricot cultivars and establishing the first incompatibility group in apricot. J. Amer. Soc. Hort. Sci. 121:10021005.

Entani, T., M. Iwano, H. Shiba, S.F. Che, A. Isogai, and S. Takayama. 2003. Comparative analysis of the self-incompatibility $(S$-) locus region of Prunus mume: Identification of a pollen-expressed F-box gene with allelic-diversity. Genes Cells 8:203-213.

Ercisli, S. 2004. A short review of the fruit germplasm resources of Turkey. Genet. Resources Crop Evol. 51:419-435.
Faust, M., D. Surányi, and F. Nyujtó. 1998. Origin and dissemination of apricot. Hort. Rev. (Amer. Soc. Hort. Sci.) 22:225-266.

Food and Agriculture Organization of the United Nations. 2008. Crops data. 3 May 2010. <http://faostat.fao.org/site/567/default.aspx>.

Guerra, M.E., J. Rodrigo, M. López-Corrales, and A. Wünsch. 2009. $S$-RNase genotyping and incompatibility group assignment by PCR and pollination experiments in japanese plum. Plant Breed. 128:304311.

Gülcan, R., A. Misirli, H. Saglam, H.A. Ölmez, S. Paydas, K. Derin, S. Eti, and T. Demir. 2006. Properties of Turkish apricot land races. Acta Hort. 701:191-197.

Halász, J. 2007. Molecular background of the $S$-locus controlled selfincompatibility in apricot. PhD Diss., Corvinus University of Budapest, Budapest, Hungary.

Halász, J., A. Fodor, A. Pedryc, and A. Hegedűs. 2010. S-genotyping of eastern European almond cultivars: Identification and characterization of new $\left(S_{36}-S_{39}\right)$ self-incompatibility ribonuclease alleles. Plant Breed. 129:227-232.

Halász, J., A. Hegedűs, R. Hermán, E. Stefanovits-Bányai, and A. Pedryc. 2005. New self-incompatibility alleles in apricot (Prunus armeniaca L.) revealed by stylar ribonuclease assay and $S$-PCR analysis. Euphytica 145:57-66.

Halász, J., A. Hegedűs, Z. Szabó, J. Nyéki, and A. Pedryc. 2007b. DNA-based $S$-genotyping of japanese plum and pluot cultivars to clarify incompatibility relationships. HortScience 42:46-50.

Halász, J., A. Pedryc, and A. Hegedûs. 2007a. Origin and dissemination of the pollen-part mutated $S_{\mathrm{C}}$-haplotype that confers self-compatibility in apricot (Prunus armeniaca). New Phytol. 176:793-803.

Harsányi, J. 1981. Fontosabb kajszifajtáink, p. 83-109. In: F. Nyujtó and D. Surányi (eds.). Kajszibarack. Mezőgazdasági Kiadó, Budapest, Hungary.

Kostina, K.F. 1969. The use of varietal resources of apricots for breeding. Trudy Nikitskiy Botanicheskiy Sad 40:45-63. (in Russian). Kostina, K.F. 1970. Self-fertility studies in apricot. Trudy Gosudarstvenny Nikitkiy Botanicheskiy Sad 45:7-17. (in Russian).

Ledbetter, C.A. 2008. Apricots, p. 39-82. In: J.F. Hancock (ed.). Temperate fruit crop breeding. Springer, New York. 
Maghuly, F., E.B. Fernandez, S. Ruthner, A. Pedryc, and M. Laimer. 2005. Microsatellite variability in apricots (Prunus armeniaca L.) reflects their geographic origin and breeding history. Tree Genet. Genomes 1:151-165.

McClure, B.A., V. Haring, P.R. Ebert, M.A. Anderson, R.J. Simpson, F. Sakiyama, and A.E. Clarke. 1989. Style self-incompatibility gene products of Nicotiana alata are ribonucleases. Nature 342:955-957.

Mehlenbacher, S.A., V. Cociu, and L.F. Hough. 1991. Apricots (Prunus), p. 65-107. In: J.N. Moore and J.R. Ballington (eds.). Genetic resources of temperate fruit and nut crops, Chap. 2. International Society for Horticultural Science, Wageningen, The Netherlands.

Misirli, A., H. Saglam, R. Gülcan, H.A. Ölmez, and M. Sahin. 2006. Investigations on fertilization biology of important dried apricot cultivars. Acta Hort. 701:159-162.

Ortega, E., R.I. Boškovic, D.J. Sargent, and K.R. Tobutt. 2006. Analysis of $S$-RNase alleles of almond (Prunus dulcis): Characterization of new sequences, resolution of synonyms and evidence of intragenic recombination. Mol. Genet. Genomics 276:413-426.

Romero, C., S. Vilanova, L. Burgos, J. Martínez-Calvo, M. Vicente, G. Llácer, and M.L. Badenes. 2004. Analysis of the $S$-locus structure in Prunus armeniaca L.: Identification of $S$-haplotype specific $S$-RNase and F-box genes. Plant Mol. Biol. 56:145-157.

Schuster, M., H. Flachowsky, and D. Köhler. 2007. Determination of self-incompatible genotypes in sweet cherry (Prunus avium L.) accessions and cultivars of the German Fruit Gene Bank and from private collections. Plant Breed. 126:533-540.

Sonneveld, T., K.R. Tobutt, and T.P. Robbins. 2003. Allele-specific PCR detection of sweet cherry self-incompatibility (S) alleles S1 to S16 using consensus and allele-specific primers. Theor. Appl. Genet. 107:1059-1070.

Sutherland, B.G., T.P. Robbins, and K.R. Tobutt. 2004. Primers amplifying a range of Prunus S-alleles. Plant Breed. 123:582-584.

Szabó, Z. and J. Nyéki. 1991. Blossoming, fructification and combination of apricot varieties. Acta Hort. 293:295-302.

Tobutt, K.R., T. Sonneveld, Z. Bekefi, and R. Boškovic. 2005. Cherry (in)compatibility genotypes: An updated cultivar table. Acta Hort. 663:667-671.

Vilanova, S., M.L. Badenes, L. Burgos, J. Martínez-Calvo, G. Llácer, and C. Romero. 2006. Self-compatibility of two apricot selections is associated with two pollen-part mutations of different nature. Plant Physiol. 142:629-641.

Vilanova, S., C. Romero, G. Llácer, M.L. Badenes, and L. Burgos. 2005. Identification of self-(in)-compatibility alleles in apricot by PCR and sequence analysis. J. Amer. Soc. Hort. Sci. 130:893-898.

Wu, J., C. Gu, S.L. Zhang, S.J. Zhang, H.Q. Wu, and W. Heng. 2009. Identification of $S$-haplotype-specific $S$-RNase and $S F B$ alleles in native Chinese apricot (Prunus armeniaca L). J. Hort. Sci. Biotechnol. 160:241-248. 